UDC: $\mathbf{6 8 1 . 8 3 3 . 6}$

\title{
EXPERIMENTAL STUDIES OF THE INERTIAL SAFETY CLUTCH FOR SCREW CONVEYOR
}

\author{
Vasyl Karetin; Petro Stukhlyak; Andrii Kurko
}

\author{
Ternopil Ivan Puluj National Technical University, Ternopil, Ukraine
}

\begin{abstract}
Summary. Devices that automatically shut down the working mechanisms when they are overloaded include friction, electromagnetic and other couplings. They allow adjusting the amount of allowable torque and automatically turning on the mechanisms when the overload stops. According to the results of the implementation of the planned factor experiments, the regression equations are obtained, which describe the change of the braking torque of the output shaft of the inertial safety clutch. The results of the study are the prerequisites for the development of methods for substantiating the rational parameters of the operation of inertial safety clutches.
\end{abstract}

Key words: kinematic scheme, imbalance, braking torque, rotational speed, gear ratio.

Statement of the problem. Efficiency and reliability of machines operation to great extend depends on the correct choice of their component schemes, calculation and substantiation of rational structural, kinematic and dynamic parameters, as well as ensuring high-precision and sufficient protection of their working parts and machine drives when overloads occur [1].

Devices which automatically shut down the working mechanisms when they are overloaded include frictional, electromagnetic, inertia and other couplings. They allow adjusting the amount of allowable torque and automatically turning on the mechanisms when the overload stops.

Analysis of available investigation results. Well-known classical approaches to the research methods of safety clutches are based on the analysis of the generalized models of inertial mechanisms [2-7] in the stated abstract way [8-12]. Therefore, there is a need for a comprehensive technological analysis of the process of inertial safety clutches together with the power units or actuating mechanisms. In present research, the so-called 'stop' mode of inertia safety clutch operation, set by the braking device, is described. In this case, the braking device simulates the magnitude of the power overload of the working body of the actuator, or the resulting process of unpredicted failure of the actuator.

Due to the 'stop' mode of inertia safety clutch operation, the possibility of failure or breaking of the working tools of the actuating mechanism are eliminated, which prevents the occurrence of emergencies and their further consequences.

Objective of the research is to substantiate rational constructive-kinematic and technological parameters of the model sample of the inertial safety clutch on the basis of the conducted experimental researches of the laboratory installation; to determine and analyze the functional dependence of the change of output shaft braking torque of the inertial safety clutch at the 'stop' operation mode.

Statement of the problem. The object of experimental research is the technological process of the model of the inertial safety clutch, and the subject of research is its design and kinematic parameters and the degree of influence of input parameters on the braking torque of the output shaft, which regulates its 'stop' mode. 'Stop' mode of operation of the inertial safety 
clutch functions in case of overload of the working tools of the actuator, for example, in agricultural machines, machines for bakery production. Such actuators can be, for example, threshing drums of combine harvesters, cutting mechanisms of mowers, working bodies of root and potato harvesting equipment, working tools of machines for processing agricultural products, in dough kneading machines and so on.

Implementation of experimental studies to determine the braking torque of the output shaft of the inertial safety clutch was carried out on the basis of well-known scientific methods for setting and conducting experiments [13], i.e. by applying the general structural scheme (model) of the experiment developed according to the common statements describing the notion of 'black box' [14]. The 'black box' describes and characterizes the general methodology, as well as the general method of conducting an experimental research of the object of study.

As the initial parameter, or parameter that functionally describes the nature of changes in the technological performance of the inertial safety clutch, and due to which its design and kinematic parameters were improved, the braking torque $M_{b t}$ of the output shaft of the inertial safety clutch [15] was taken, which was determined for a combination of two variants and two cases of its operation.

Experimental studies were performed using the designed experimental stand. Structural and technological scheme of the experimental stand, which is designed for experimental research of technological indicators of the process of ISC operation, is shown in Fig. 1. The general view of the experimental stand is shown in Fig. 2.

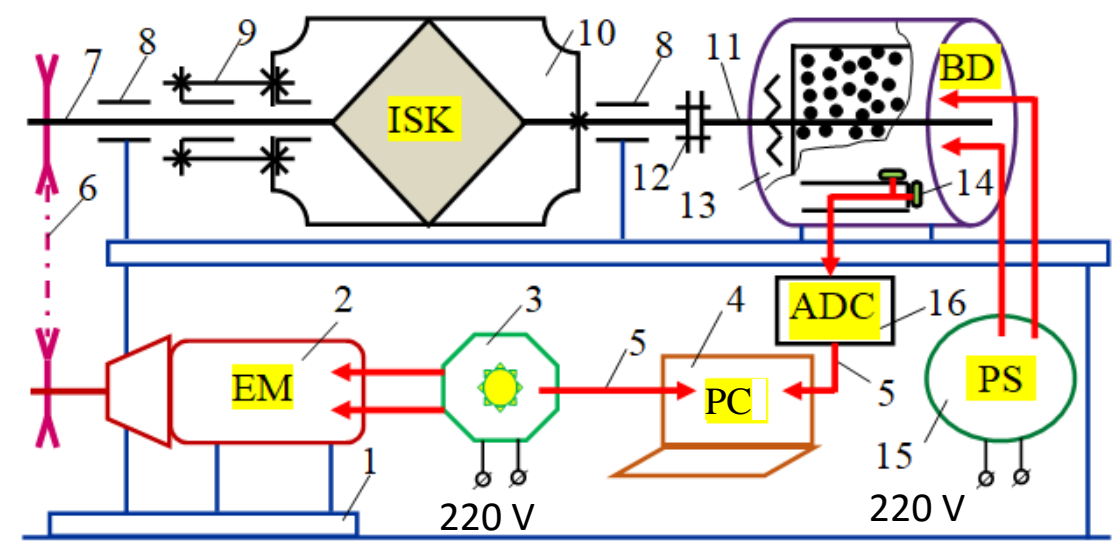

Figure 1. Structural and technological scheme of the experimental stand: 1 - main frame; 2 - electric motor; 3 - device for speed control of the Altivar 71 motor; 4 - personal computer; 5 - switching connection; 6-V-belt transmission; 7, 11 - respectively, the input and output shaft of the inertial safety clutch; 8 - bearing support; 9 - glass; 10 - inertial safety clutch; 12 - toothed coupling;

13 - electromagnetic powder brake device; 14 - strain gauges; 15 - analog-to-digital converter; 16 - power supply; EM - electric motor; $\mathrm{PC}$ - personal computer; ADC - analog-to-digital converter; PS - power supply; BD - brake device

Experimental stand consists of the main frame 1 (Fig. 1, Fig. 2) on which the main working blocks are installed: 4A80A4CV1-type induction electric motor, multisystem control device 3 Altivar 71, inertial safety clutch 10, electromagnetic powder brake device 13, stepwise regulative power supply 15 .

The Altivar 71 device is designed for step control of the electric motor shaft speed. The brake device is made as electromagnetic powder loading brake of PB-16M1 type. Power supply is connected to the induction coils of the brake device PB-16M1.

The input shaft 9 of the inertial safety clutch, which is mounted in series in the support 
8, mounted on the main frame of the experimental stand and in the glass 10 fixed on the side of the inertial safety clutch case, is connected to the motor shaft 4A80A4CY1 with a V-belt transmission 6.

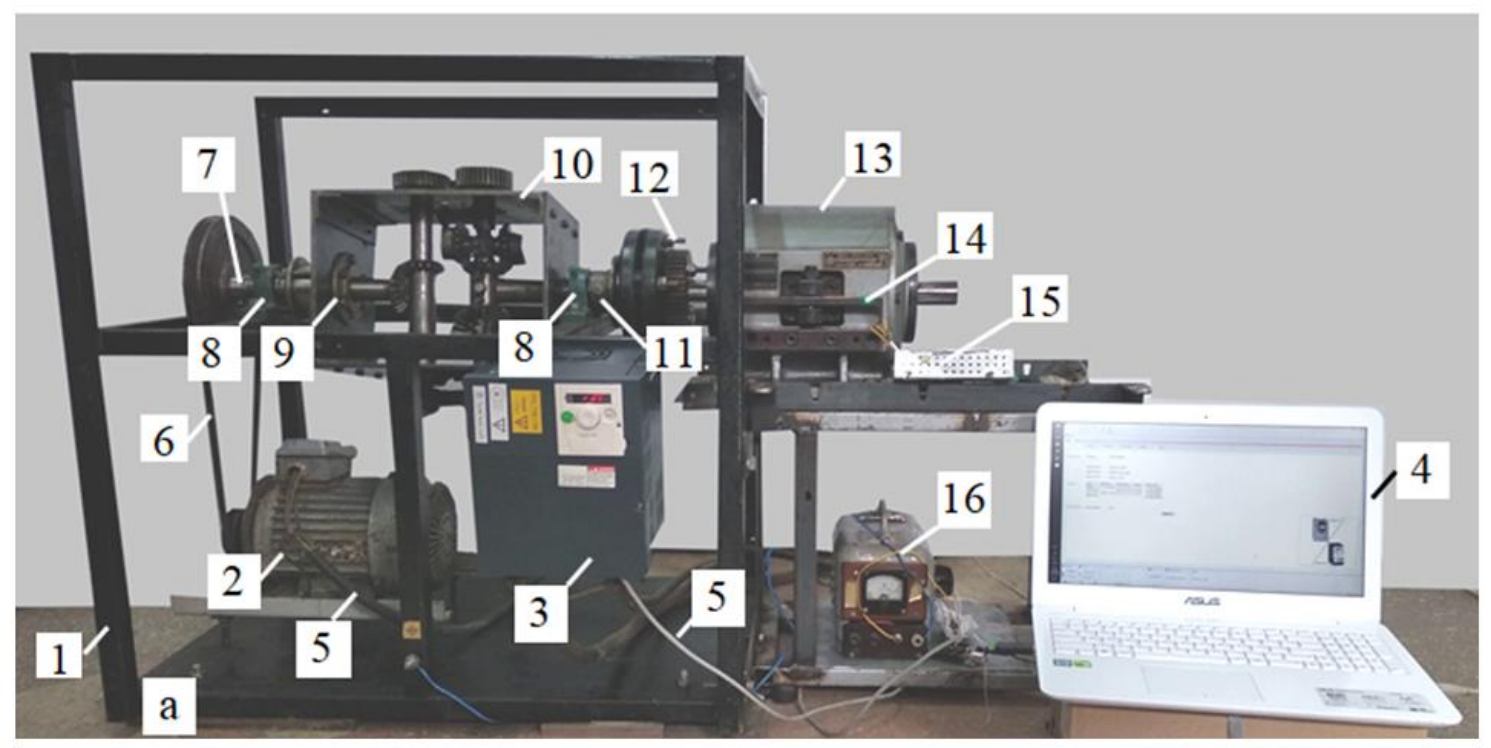

Figure 2. General view of the experimental stand: 1 - main frame; 2 - electric motor; 3 - device for speed control of the Altivar 71 motor; 4 - personal computer; 5 - switching connection; 6 - V-belt transmission; 7, 11 - respectively, the input and output shaft of the inertial safety clutch; 8 - bearing support; 9 - glass; 10 - inertial safety clutch; 12 - toothed coupling; 13 - electromagnetic powder brake device; 14 - strain gauges; 15 - analog-to-digital converter; 16 - power supply

The output shaft 11 of the inertial safety clutch is mounted in a bearing support 8 , which is fixed on the main frame of the experimental stand and is connected to the shaft of the electromagnetic powder loading brake 13 of PB-16M1 type with a toothed coupling 12.

Electric motor, strain-gauge transducers 14 mounted on calibrating device ПТ-16M1 for calibrating the amount of braking torque on its shaft and of the electromagnetic induction coils winding of the braking device PT-16M1 with communication connection 5, are connected, respectively, to Altivar 71 device, analogue-to-digital converter (ADC) and stepwise power supply control.

The kinematic scheme of the experimental stand is shown in Fig. 3.

Technological process of the experimental stand operation is as follows.

$220 \mathrm{~V}$ power supply was connected to the Altivar 71 multisystem control unit 3 (Fig. 1, Fig. 2). The start button, which is located on the panel of Altivar 71 control device 3, switched on the supply voltage of the electric motor 2 and, accordingly, rotated the motor shaft. Due to the V-belt transmission 6, the torque of the motor shaft to the input shaft 9 of the inertial safety clutch 10 is transmitted.

Then, the operation principle, or the technological process of operation of the inertial safety clutch, is identical to the operation principle of the inertial safety clutch, described in [16]. Subsequently, the rotational movement of the output shaft 19 (Fig. 3) of the inertial safety clutch 3 through the connecting gear clutch 20 is transmitted to the shaft 21 of the brake device 22.

The speed of the input shaft 7 (Fig. 1, Fig. 2) of the inertial safety clutch 10 is regulated by the frequency converter of the control device 3 Altivar 71 using the standard licensed software Power Suite V2.3.0. The technological load of the brake device 13 (electromagnetic powder brake device PB-16M1) was simulated using the Arduino control system [17]. 


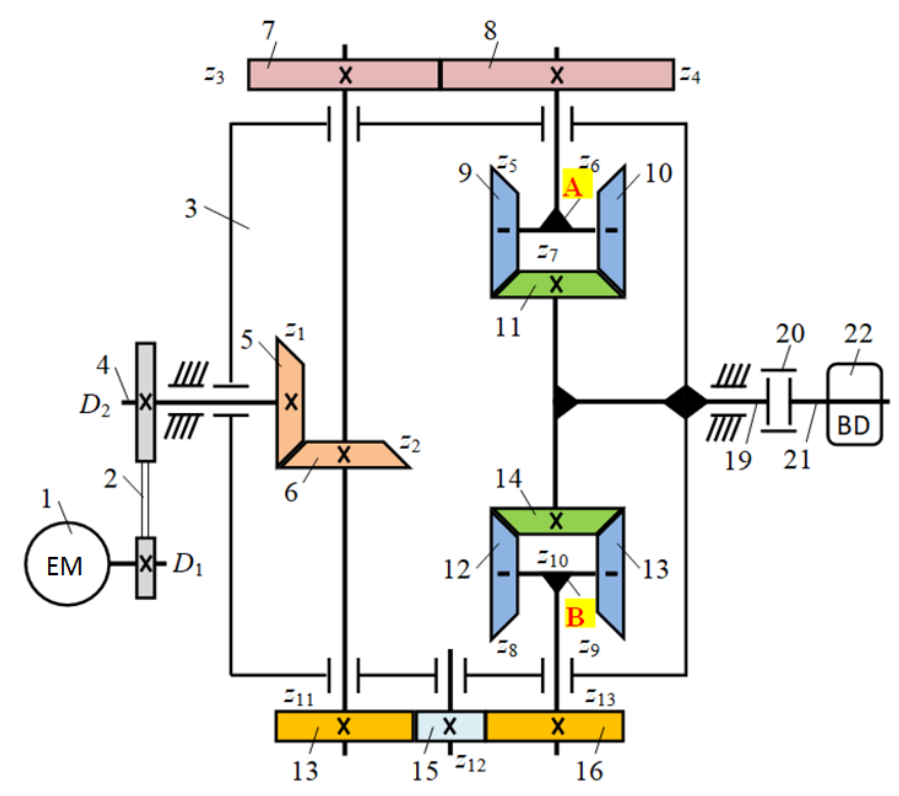

Figure 3. Kinematic scheme of the experimental stand: 1 - electric motor; 2 - V-belt transmission; 3 - inertial safety clutch; 4 - input shaft; 5, 6, 9-14 - bevel gears; 7, 8, 14, 16 - straight-toothed cylindrical gears; 15 - straight-toothed parasitic cylindrical gear; 19 - output shaft; 20 - gear coupling; 21 - a shaft of

the brake device; 22 - brake device; A - the upper drive of the imbalance; B - the lower drive of the imbalance

On the computer monitor in the field of the window of the virtual oscilloscope in the system of Cartesian coordinates the diagrams of frequency characteristics are reproduced and the diagram designations due to the appearance of the legend are displayed. The operating modes of the oscilloscope and its instantaneous state of data reproduction are set by the trigger. The 'stop' mode of clutch operation is modeled by the brake torque value.

To obtain a regression model that describes the change of the initial parameters and allows to optimize the process of the inertial safety clutch operation, the appropriate plan of a two-factor planned experiment of PFE $3^{2}$ type was chosen.

The names of natural factors, variation levels and the results of their coding are given in Table 1.

Table 1

Levels of variation and designation (coding) of natural factors

\begin{tabular}{|c|c|c|c|c|}
\hline $\begin{array}{c}\text { Name and } \\
\text { designation of the real factor }\end{array}$ & $\begin{array}{c}\text { Variation } \\
\text { interval }\end{array}$ & \multicolumn{3}{|c|}{$\begin{array}{c}\text { Variation level values: } \\
\text { natural/coded }\end{array}$} \\
\hline Input shaft speed $n_{i s}, \mathrm{rpm}$ & 175 & $87,5 /(-1)$ & $262,5 /(0)$ & $437,5 /(+1)$ \\
\hline Gear ratio $u_{z}$ & 1,05 & $1,1 /(-1)$ & $2,15 /(0)$ & $3,2 /(+1)$ \\
\hline
\end{tabular}

The order of numerical implementation of experiments was performed according to the plan-matrix and according to known standard methods due to the established current criteria, requirements and recommendations [18].

The obtained results of numerical values: input shaft speed $n_{i s}$, the braking torque $M_{b t}$ of the output shaft and the corresponding value of the gear ratio $u_{z}$ of upper imbalance drive of the inertial safety clutch were recorded in the table. Processing of the obtained experimental data set was performed according to a well-known method [19]. 
The coefficients of the approximating function, represented as a functional dependence $M_{b t}=f_{M}\left(u_{z} ; n_{i s}\right)$ under conditions of orthogonality and symmetry of the experimental plan matrix, were determined using Statistica 10 personal computer software [20, 21].

Analysis of numerical results. Studies of the functional nature of braking torque $M_{b t}$ change of the output shaft were carried out for the following combinations of two variants and two cases of operation of the inertial safety clutch: combination with reverse and intermediate gear $M_{r . p}, \mathrm{Nm}$ (hereinafter combination $I$ ); combinations without reverse and intermediate gear $M_{\text {wr.p }}, \mathrm{Nm}$ (hereinafter combination $I I$ ).

The dependence for approximation of experimental data of braking torque $M_{b t}$ functional change of output shaft depending on the of input shaft rotation speed change $n_{i s}$ and gear ratio $u_{z}$ of the upper unbalance drive of the inertial safety clutch for combination variants $I$ and $I I$, or for determining the approximating function in the form of empirical model $M_{b t}=f_{M}\left(u_{z} ; n_{i s}\right)$ was found by the maximum value of the coefficient of multiple determination $D_{i}$, which was determined by working out the known algebraic functions and further analysis of its numerical values.

The functional dependence $M_{b t}=f_{M}\left(u_{z} ; n_{i s}\right)$ for approximation of the experimental data of the braking torque change $M_{b t}$ of the output shaft of inertial safety clutch for combinations $I$ and $I I$ was set as a mathematical model of a complete polynomial of the second degree

$$
M_{b t}=b_{0}+b_{1} u_{z}+b_{2} n_{i s}+b_{12} u_{z} n_{i s}++b_{11}\left(u_{z}\right)^{2}+b_{22}\left(n_{i s}\right)^{2}
$$

where $b_{0}$ is a free term of regression equation (empirical model); $b_{1}, b_{2}, b_{12}, b_{11}, b_{22}$ are respectively the coefficient of each input factor and their interaction.

The determined numerical values of the coefficients of the regression equation (1) in natural quantities, which characterize the functional change of the braking torque $M_{b t}$ of the output shaft of the inertial safety clutch and which is written down as a function $M_{b t}=f_{M}\left(u_{z} ; n_{i s}\right)$, or the change of $M_{b t}$, depending on the input shaft speed $n_{i s}$ variation, and the gear ratio $u_{z}$ of the upper imbalance gear of the inertial safety clutch for combinations $I$ and $I I$, are given in Table 2 .

Table 2

Natural values of coefficients $b_{0}, b_{i}$ and $b_{i j}$ the regression equation of braking torque change $M_{b t}$ on the output shaft of the inertial safety clutch, which is written as a function $M_{b t}=f_{M}\left(u_{z} ; n_{i s}\right)$ for combinations $I$ and $I I$

\begin{tabular}{|c|c|c|c|c|c|c|}
\hline \multirow{2}{*}{ Designations } & \multicolumn{6}{|c|}{ Natural values of the coefficients of the regression equation } \\
\cline { 2 - 7 } & $b_{0}$ & $b_{1}$ & $b_{2}$ & $b_{12}$ & $b_{11}$ & $b_{22}$ \\
\hline$M_{r . p}=f_{M}\left(u_{z} ; n_{i s}\right)$ & 0,094 & 0,31 & 0,53 & 0,01 & $-0,029$ & $6,5410^{-7}$ \\
\hline$M_{\text {wr.p }}=f_{M}\left(u_{z} ; n_{i s}\right)$ & 0,36 & 0,49 & 0,063 & 0,01 & $-0,032$ & $5,3410^{-8}$ \\
\hline
\end{tabular}


Statistical significance of the natural values of the coefficients $b_{i}$ and $b_{i j}$ of the regression equation, which is written down as an empirical model (1), was estimated according to $t$ - criterion of Student according to the condition $t_{p}<t_{T}$ for the degree of reliability $P=0,95$.

Having neglected insignificant coefficients $b_{22}=6,5410^{-7} ; 5,3410^{-8}$ (Table 2), we obtain a regression equation in natural quantities, which is written down as a function $M_{b t}=f_{M}\left(u_{z} ; n_{i s}\right)$ and characterizes and functionally describes the change in braking torque $M_{b t}$ of the output shaft of the inertial safety clutch depending on the input shaft rotation speed $n_{i s}$ and the gear ratio $u_{z}$ of the upper drive unbalance of inertial safety clutch for combinations $I$ and $I I$ :

- for combination variant $I$ (with reverse and with intermediate gear) $M_{r . p}$ :

$$
M_{r . p}=0,094+0,31 u_{z}+0,53 n_{i s}+0,01 u_{z} n_{i s}-0,29\left(u_{z}\right)^{2}
$$

- for combination variant $I I$ (with no reverse and with intermediate gear) $M_{w r . p}$

$$
M_{w r . p}=0,36+0,49 u_{z}+0,063 n_{i s}+0,01 u_{z} n_{i s}-0,32\left(u_{z}\right)^{2}
$$

Verification of the adequacy or compliance of regression models (2), (3) with the obtained array of experimental data of the braking torque $M_{b t}$ change of the output shaft of the inertial safety clutch was carried out according to the appropriate Fisher's F-criterion due to condition $F_{p}<F_{T}$ with the degree of reliability $P=0,95$ and when the value of reliability of multiple determination coefficient $D_{n}=1,0$ with probability $P=0,95$, as well as with the value of the multiple correlation coefficient $R$.

Based on the results of the obtained experimental values and according to the regression equations (2) and (3), the response surfaces and two-dimensional cross-sections of the response surfaces are drawn, which describe and characterize the functional change of the brake torque $M_{b t}$ of the output shaft depending on the change of gear ratio $u_{z}$ of upper imbalance drive and rotation speed of the inertial safety clutch as functions $M_{b t}=f_{M}\left(u_{z} ; n_{i s}\right)$ for the accepted combinations $I$ and $I I$ :

- for combination variant $I$ (with reverse and with intermediate gear) as a function $M_{r . p}=f_{M}\left(u_{z} ; n_{i s}\right)$, Fig. 4 a.

- for combination variant $I I$ (with no reverse and with intermediate gear) as a function $M_{w r . p}=f_{M}\left(u_{z} ; n_{i s}\right)$, Fig. 4 b. 

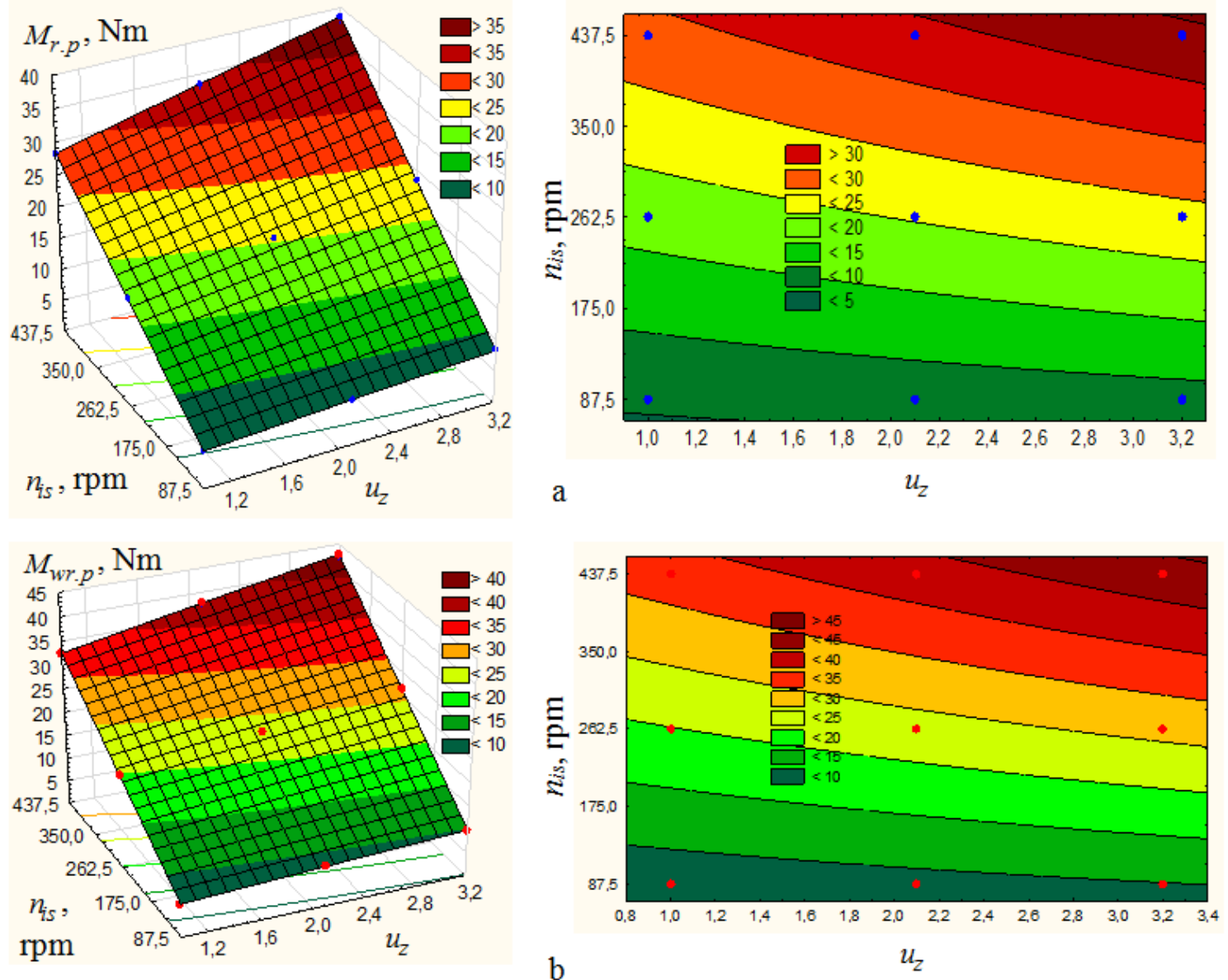

Figure 4. Response surface and two-dimensional cross-section of the response surface: $\mathrm{a}-$ functions $M_{p . r}=f_{M}\left(u_{z} ; n_{i s}\right) ; \mathrm{b}$-functions $M_{w r . p}=f_{M}\left(u_{z} ; n_{i s}\right)$

Analysis of the diagramed reproductions in the form of response surfaces and their twodimensional cross sections shows that the main component that has a significant effect on the change of the braking torque $M_{b t}$ of the output shaft for the accepted working process combinations $I$ and $I I$ is the rotation speed $n_{i s}$ of the input shaft of inertial safety clutch. Concurrently, with increasing speed $n_{i s}$ of the input shaft in the range from $87.5 \mathrm{rpm}$ to $437.5 \mathrm{rpm}$, the braking torque $M_{b t}$ of the output shaft, which provides a 'stop' mode of the inertial safety clutch operation also increases within the following limits:

- for combination variant $I$ (with reverse and with intermediate gear) as a function $M_{r . p}=f_{M}\left(u_{z} ; n_{i s}\right)$ from 4.5 to 4.8 times, which is characteristic to Fig. 4 a;

- for combination variant $I I$ (with no reverse and with intermediate gear) as a function $M_{w r . p}=f_{M}\left(u_{z} ; n_{i s}\right)$ from 3.9 to 4.7 times, which is characteristic to Fig. 4 b.

Herewith, the nature of the functional change of the braking torque $M_{b t}$ of the output shaft for working process combinations $I$ and $I I$ depending on the increase in rotation speed $n_{i s}$ of the input shaft of the inertial safety clutch is close to proportional - with a proportional increase in 
rotation speed $n_{i s}$ up to 5 times (from $87.5 \mathrm{rpm}$ to $437.5 \mathrm{rpm}$ ) the braking torque $M_{b t}$ of the output shaft also increases in proportion to the increase $n_{i s}$ and is from 4.8 to 5.1 times.

Increasing the gear ratio $u_{z}$ in the range from 1 to 3.2 for the combination variants $I$ and II (using the intermediate gear drive of the upper imbalance of the inertial safety clutch) does not significantly affect the increase in braking torque $M_{b t}$ of the output shaft within the input shaft rotation speed $n_{i s}$ of the inertial safety clutch from $87.5 \mathrm{rpm}$ to $262.5 \mathrm{rpm}$, which is typical of the analysis of diagrams, shown in Fig. 4.

In this case, the braking torque $M_{b t}$ of the output shaft of the inertial safety clutch increases in a small range -from 3.0 Nm to $4.0 \mathrm{Nm}$ on average. Within the limits of increasing the rotation speed $n_{i s}$ of the input shaft of the inertial safety clutch from $262.5 \mathrm{rpm}$ to $437.5 \mathrm{rpm}$ and changing the gear ratio $u_{z}$ from 1 to 3.2 , the increase in braking torque $M_{b t}$ for the variant combinations $I$ and $I I$ of the inertial safety clutch operation is on average from $8.0 \mathrm{Nm}$ to $10.0 \mathrm{Nm}$. This statement is also confirmed by the nature of the analysis of the functional curves changes $M_{b t}$, which are shown in two-dimensional sections of the response surfaces, shown in Fig. 4.

Couclusions. Based on comparisons and analysis of diagramed changes of brake torque $M_{b t}$ of output shaft for combination variants $I$ and $I I$ (with intermediate gear of the drive of the top unbalance of the inertial safety clutch, Fig. 4) depending on change of rotation speed $n_{i s}$ of input shaft from $87.5 \mathrm{rpm}$ to $437.5 \mathrm{rpm}$ and changes in gear ratio $u_{z}$ from 1 to 3.2 , it can be stated that:

- the process of operation of the inertial safety clutch with the use of reverse and with intermediate gear drive of the upper unbalance (combination variant $I$, when the upper and lower unbalance have counter-rotation) provides an increase in brake torque $M_{r . p}$ of the output shaft of inertial safety clutch on average by $10 \ldots 15 \%$ or by $1.1 \ldots 1.15$ times compared to the combination variant $I I$ with no reverse and with an intermediate gear;

- a significant increase in the torque transmission $M_{b t}$ of the output shaft for cases of comparing the operation process combinations $I$ and $I I$ (on average by $15 \ldots 20 \%$ ) occurs at the rotation speed of the input shaft of the inertial safety clutch $n_{i s} \geq 262.5 \mathrm{rpm}$;

- the maximum values of occurance of braking torque $M_{b t \text {.max }}$ of the output shaft, or the optimal mode of the inertial safety clutch operation is provided when using the combination variant $I I$, i.e. when applying the process of inertial safety clutch operation with no reverse and with intermediate gear, in which the upper and lower unbalance drives counter-rotate. Herewith, the average maximum values of the braking torque $M_{w r . p . m a x}$ of the output shaft of the inertial safety clutch, which vary in the range from $25 \mathrm{Nm}$ to $43 \mathrm{Nm}$, obtained by changing the rotation speed $n_{i s}$ of the input shaft in the range from $262.5 \mathrm{rpm}$ to $437.5 \mathrm{rpm}$ and the gear ratio $u_{z}$ of the upper imbalance from 2.0 to 3.2 .

Thus, in the context of providing the maximum braking torque $M_{b t \text {.max }}$ of the output shaft, the rational parameters of the inertial safety clutch operation process are in the following range: the rotation speed of the input shaft is from $87.5 \mathrm{rpm}$ to $437.5 \mathrm{rpm}$; gear ratio of the 
upper imbalance drive is from 2.0 to 3.2; gear ratio of the lower imbalance drive is 1.0. In the future, it is planned to carry out the mechanism operation in other technological modes.

\section{References}

1. Klendii O. M. Obgruntuvannia parametriv zapobizhnykh muft hvyntovykh konveieriv. Dys. kand. tekhn. nauk: 05.02.02. Ternopil, 2015. 178 p. [In Ukrainian].

2. Leonov A. I. Inercionnye avtomaticheskie transformatory vrashhajushhego momenta. Moskva: Mashinostroenie, 1978, 224 p. [In Russian].

3. Berselli G. et al., 'Kinematic design and bond graph modeling of an inertia-type infinitely variable transmission,' Proceedings of the ASME Design Engineering Technical Conference, 5, 2008. DOI: https://doi.org/10.1115/DETC2008-49875

4. Benitez F. G. et al., 'Infinitely Variable Transmission of Racheting Drive Type Based on One-Way Clutches,' ASME. Journal of Mechanical Design. July 2004, 126 (4). P. 673-682. DOI: https://doi.org/10.1115/1.1758258

5. Aliukov S. et al., 'Analysis of Methods for Solution of Differential Equations of Motion of Inertial Continuously Variable Transmissions,' SAE Technical Paper. 2017. DOI: https://doi.org/10.4271/2017-01-1105

6. Marchuk R., Komar R., Dubynyak T., Flonts O., Dynya V., Semeniv I. (2017) Substantiation of the parameters of hydraulic overload clutch. Scientific Journal of TNTU (Tern.). Vol. 86. No 2. P. 59-66. [In English].

7. Lutsiv I., Hevko I., Dubynyak T., Manzii O. (2017) Defining parameters of elastic-safety clutches for screw conveyers. Scientific Journal of TNTU (Tern.). Vol. 87. No 3. P. 72-80. [In English]. DOI: https://doi.org/10.33108/visnyk_tntu2017.03.072

8. Liu K. et al.,'Dynamic Analysis of an Overrunning Clutch for the Pulse-Continuously-VariableSpeed Transmission,' SAE Technical Paper, 1998. DOI: https://doi.org/10.4271/980827

9. Ince E. et al., 'On the advantages of the new power-split infinitely variable transmission over conventional mechanical transmissions based on fuel consumption analysis. Journal of Cleaner Production, 2020. DOI: https://doi.org/10.1016/j.jclepro.2019.118795

10. Tsuchiya E. et al., 'Formulation of intervibrator motion and development of a controller for a pulse-drive transmission,' Mechanism and Machine Theory. Vol. 150. DOI: https://doi.org/10.1016/j.mechmachtheory.2020.103880

11. Liang J. et al.,' Simulation Study on Planetary Bevel Gear CVT System Based on Virtual Prototyping Technology,' Applied Mechanics and Materials. 215-216. 1003-1008. DOI: https://doi.org/10.4028/www.scientific.net/AMM.215-216.1003

12. Strilets O., Malashchenko V., Strilets V. (2020) Dynamic model of a closed-loop hydraulic system for speed control through gear differential. Scientific Journal of TNTU (Tern.). Vol 98. No. 2. P. 91-98. DOI: https://doi.org/10.33108/visnyk_tntu2020.02.091

13. Lunev V. A. Matematicheskoe modelirovanie i planirovanie jeksperimenta: Ucheb. posobie. SPb., $153 \mathrm{p}$. [In Russian].

14. Spirin N. A. [i dr.] Metody planirovanija i obrabotki rezul'tatov inzhenernogo jeksperimenta: uchebnoe posobie / pod red. N. A. Spirina; GOU VPO UGTU - UPI. Ekaterinburg, 2015. 290 p. [In Russian].

15. Karetin, V. (2020). Kinematic study of the standard layout circuit of the inertia module. Scientific Horizons, 07 (92), 104-111. DOI: https://doi.org/10.33249/2663-2144-2020-92-7-104-111

16. Karetin V. M., Kurko A. M. Kompiuteryzovanyi stend dlia eksperymentalnoho doslidzhennia enerhetychnykh kharakterystyk inertsiinoho dyferentsialnoho transformatora momentu: zb. tez. dop. Materialy XXI naukovoi konferentsii TNTU imeni Ivana Puliuia. Ternopil, 2019. P. 87. [In Ukrainian].

17. Karetin V. M., Kurko A. M., Mykhailyshyn M. S. Avtomatyzovana reiestratsiia parametriv potuzhnosti inertsiinoho dyferentsialnoho transformatoru momentu. Teoretychni ta prykladni aspekty radiotekhniky, pryladobuduvannia i kompiuternykh tekhnolohii: zb. tez. dop. Materialy IV Mizhnarodnoi naukovotekhnichnoi konferentsii. Ternopil, 2019. P. 186-187. [In Ukrainian].

18. Rogov V. A. Metodika i praktika tehnicheskih jeksperimentov: uchebnoe posobie. Moskva: Akademija, 2005. 288 p. [In Russian].

19. Shashkov V. B. Prikladnoj regressionnyj analiz: uchebnoe posobie. Orenburg: GOU VPO OGU, 2003. 363 p. [In Russian].

20. Sidnjaev N. I. Teorija planirovanija jeksperimenta i analiz statisticheskih dannyh. Uchebnoe posobie. M: Jurajt, 2015. 496 p. [In Russian].

21. Halafjan A. Promyshlennaja statistika. Kontrol' kachestva, analiz processov, planirovanie jeksperimentov v pakete STATISTICA. M: Librokom, 2013. 384 p. [In Russian].

\section{Список використаної літератури}


1. Клендій О. М. Обгрунтування параметрів запобіжних муфт гвинтових конвеєрів: дис. ... канд. техн. наук: 05.02.02. Тернопіль, 2015. 178 с.

2. Леонов А. И. Инерционные автоматические трансформаторы вращающего момента. Москва: Машиностроение, 1978, 224 с.

3. Berselli G. et al., 'Kinematic design and bond graph modeling of an inertia-type infinitely variable transmission,' Proceedings of the ASME Design Engineering Technical Conference, 5, 2008. DOI: https://doi.org/10.1115/DETC2008-49875

4. Benitez F. G. et al., 'Infinitely Variable Transmission of Racheting Drive Type Based on One-Way Clutches,' ASME. Journal of Mechanical Design. July. 2004. 126 (4). 673-682. DOI: https://doi.org/10.1115/1.1758258

5. Aliukov S. et al., 'Analysis of Methods for Solution of Differential Equations of Motion of Inertial Continuously Variable Transmissions,' SAE Technical Paper, 2017. DOI: https://doi.org/10.4271/2017-01-1105

6. Marchuk R., Komar R., Dubynyak T., Flonts O., Dynya V., Semeniv I. Substantiation of the parameters of hydraulic overload clutch. Scientific Journal of TNTU (Tern.). 2017. Vol. 86. No. 2. P. 59-66.

7. Lutsiv I., Hevko I., Dubynyak T., Manzii O. Defining parameters of elastic-safety clutches for screw conveyers. Scientific Journal of TNTU (Tern.). 2017. Vol. 87. No. 3. P. 72-80. DOI: https://doi.org/10.33108/visnyk_tntu2017.03.072

8. Liu K. et al.,'Dynamic Analysis of an Overrunning Clutch for the Pulse-Continuously-VariableSpeed Transmission,' SAE Technical Paper, 1998. DOI: https://doi.org/10.4271/980827

9. Ince E. et al., 'On the advantages of the new power-split infinitely variable transmission over conventional mechanical transmissions based on fuel consumption analysis, 'Journal of Cleaner Production, 2020. DOI: https://doi.org/10.1016/j.jclepro.2019.118795

10. Tsuchiya E. et al., " Formulation of intervibrator motion and development of a controller for a pulse-drive transmission,' Mechanism and Machine Theory. Vol. 150. DOI: https://doi.org/10.1016/j.mechmachtheory.2020.103880

11. Liang J. et al.,' Simulation Study on Planetary Bevel Gear CVT System Based on Virtual Prototyping Technology,' Applied Mechanics and Materials. 215-216. 1003-1008. DOI: https://doi.org/10.4028/www.scientific.net/AMM.215-216.1003

12. Strilets O., Malashchenko V., Strilets V. Dynamic model of a closed-loop hydraulic system for speed control through gear differential. Scientific Journal of TNTU (Tern.). 2020. Vol. 98. No. 2. P. 91-98. DOI: https://doi.org/10.33108/visnyk_tntu2020.02.091

13. Лунев В. А. Математическое моделирование и планирование эксперимента: учеб. пособие. СПб., 153 с.

14. Спирин Н. А. и др. Методы планирования и обработки результатов инженерного эксперимента: учебное пособие / под ред. Н. А. Спирина; ГОУ ВПО УГТУ - УПИ. Екатеринбург, 2015. 290 с.

15. Karetin, V. Kinematic study of the standard layout circuit of the inertia module. Scientific Horizons. 2020. 07 (92). P. 104-111. DOI: https://doi.org/10.33249/2663-2144-2020-92-7-104-111

16. Каретін В. М., Курко А. М. Комп'ютеризований стенд для експериментального дослідження енергетичних характеристик інерційного диференціального трансформатора моменту: зб. тез. доп. Матеріали XXI наукової конференції Тернопільського національного технічного університету імені Івана Пулюя. Тернопіль, 2019. С. 87.

17. Каретін В. М., Курко А. М., Михайлишин М. С. Автоматизована реєстрація параметрів потужності інерційного диференціального трансформаторА моменту. Теоретичні та прикладні аспекти радіотехніки, приладобудування і комп'ютерних технологій: зб. тез. доп. Матеріали IV Міжнародної науково-технічної конференції. Тернопіль, 2019. С. 186-187.

18. Рогов В. А. Методика и практика технических экспериментов: учебное пособие. Москва: Академия, 2005. 288 c.

19. Шашков В. Б. Прикладной регрессионный анализ: учебное пособие. Оренбург: ГОУ ВПО ОГУ, 2003. $363 \mathrm{c.}$

20. Сидняев Н. И. Теория планирования эксперимента и анализ статистических данных: учебное пособие. М: Юрайт, 2015. 496 с.

21. Халафян А. Промышленная статистика. Контроль качества, анализ процессов, планирование экспериментов в пакете STATISTICA. М: Либроком, 2013. 384 с. 


\title{
УДК 681.833.6
}

\section{ЕКСПЕРИМЕНТАЛЬНІ ДОСЛІДЖЕННЯ ІНЕРЦІЙНӦ̈ ЗАПОБІЖНОЇ МУФТИ ГВИНТОВОГО КОНВЕСРА}

\author{
Василь Каретін; Петро Стухляк; Андрій Курко
}

\author{
Тернопільський начіональний технічний університет імені Івана Пулюя, \\ Тернопіль, Україна
}

\begin{abstract}
Резюме. Ефективність $i$ надійність функціонування машин $i$ механізмів значною мірою залежить від правильного вибору їх компонувальних схем, розрахунку й обтрунтування раціональних конструктивних, кінематичних $i$ динамічних параметрів, а також від забезпечення високоточного $i$ надійного захисту робочих органів і приводів машин при виникненні перевантажень. До пристроїв, які автоматично вимикають робочі механізми при їх перевантаженні, відносяться фрикційні, електромагнітні, інериійні та інші з'єднувальні муфти, щзо дозволяють регулювати величину допустимого крутного моменту й автоматично включають у роботу механізми при припиненні перевантаження. За рахунок виникнення стопового режиму роботи інерційної запобіжної муфти усувається можливість виходу з ладу або поломки робочих органів виконавчого механізму, що запобігає виникненню аварійних ситуацій та їх подальших наслідків. За результатами реалізаиї планованих факторних експериментів отримано рівняння регресії, які характеризують зміну гальмівного крутного моменту вихідного вала інериійної запобіжної муфти залежно від вхідних параметрів: частоти обертання вхідного вала та передачного відношення механізму привода дебалансів. Процес роботи інериійної запобіжної муфти із застосування реверсу та з паразитною шестернею привода верхнього дебалансу (варіант комбінації I, за якого верхній $і$ нижній дебаланси мають зустрічне обертання) забезпечує збільщення передавання гальмівного крутного моменту вихідного вала інерчійної запобіжної муфти в середньому на 10..15\%, або в 1,1..1,15 раза порівняно з варіантом комбінації II без застосування реверсу та з паразитною шестернею. У контексті забезпечення максимального гальмівного крутного моменту вихідного вала раціональні параметри процесу роботи інериійної запобіжної муфти знаходяться в діапазоні: частота обертання вхідного вала від 87,5 об/хв до 437,5 об/хв; передаточне відношення привода верхнього дебалансу від 2,0 до 3,2; передаточне відношення привода нижнього дебалансу 1,0. Результати дослідження є передумовами розроблення методології та методики обгрунтування раціональних параметрів процесу функціонування інериійних запобіжних мyфm.
\end{abstract}

Ключові слова: кінематична схема, дебаланс, гальмівний крутний момент, частота обертання, передаточне відношення.

https://doi.org/10.33108/visnyk_tntu2020.04.086

Отримано 15.11.2020 